\title{
Mississippian lamprophyre dikes in western Sierras Pampeanas, Argentina: Evidence of transtensional tectonics along the SW margin of Gondwana
}

\author{
Federico Martina ${ }^{a,}{ }^{*}$, Horacio N. Canelo ${ }^{a}$, Federico M. Dávila ${ }^{a}$, \\ María Helena M. de Hollanda ${ }^{\text {b }}$, Wilson Teixeira ${ }^{\mathrm{b}}$ \\ ${ }^{a}$ CICTERRA, CONICET - Universidad Nacional de Córdoba, Av. Haya de la Torre s/n, X5015GCA, Córdoba, Argentina \\ ${ }^{\mathrm{b}}$ Instituto de Geociências, Universidade de São Paulo, São Paulo, Brazil
}

\section{A $\quad \mathrm{R}$ T I C C L E I}

\section{Article history:}

Received 22 September 2017

Received in revised form

30 January 2018

Accepted 8 February 2018

Available online 10 February 2018

\section{Keywords:}

Famatina range

Lamprophyre dike swarm

Structural analysis

${ }^{40} \mathrm{Ar} /{ }^{39} \mathrm{Ar}$ geochronology

Mississippian

SW Gondwana

\begin{abstract}
A B S T R A C T
In the Famatina range, Sierras Pampeanas of Argentina (SW Gondwana), subvertical calc-alkaline lamprophyric dike swarms crop out through $>300 \mathrm{~km}$. The dikes cut Ordovician units with a prominent NW-SE trending and are covered by continental sedimentary successions of Pennsylvanian to Permian age. The dikes show a strong structural control associated with Riedel fault systems. Detailed field analysis suggested a $\sim \mathrm{N}-\mathrm{S}$ opening direction oblique to the attitude of dike walls and a left-lateral transtensional tectonics during the emplacement. ${ }^{40} \mathrm{Ar} /{ }^{39} \mathrm{Ar}$ geochronology of a lamprophyric sample defined a crystallization age (plateau; whole rock) of $357.1 \pm 7.1 \mathrm{Ma}(\mathrm{MSWD}=2.3$ ). Coetaneous ductile zones with dominant strikeslip motion, documented along western Argentina for $>600 \mathrm{~km}$, suggest a regional event in SW Gondwana during the Mississippian. We propose that this deformation was the result of the counterclockwise fast rotation of Gondwana between 365 and $345 \mathrm{Ma}$, when the Famatina range and western Argentina occupied a sub-polar position. A transform margin along SW Gondwana better explains our (and others) data rather than a subduction margin. This scenario is also consistent with the occurrence of A-type granites and normal-fault basins within the foreland as well as bimodal volcanics.
\end{abstract}

() 2018 Elsevier Ltd. All rights reserved.

\section{Introduction}

The Late Devonian-Mississippian (Lower Carboniferous) tectonics of Gondwana has been strongly debated, with particular focus on its western margin (Ramos et al., 1998; Davis et al., 1999; Höckenreiner et al., 2003; Dahlquist et al., 2010, 2015; Martina et al., 2011; Willner et al., 2011; Alasino et al., 2012; Hyppolito et al., 2014). Most tectonic models (Bahlburg and Hervé, 1997; Ramos, 1988), supported by U-Pb provenance studies in detrital zircon (Willner et al., 2008; Bahlburg et al., 2009; Maksaev et al., 2015; Einhorn et al., 2015) indicated that Gondwana passed through a transitional stage between two clear subducting-driven settings: early-middle Paleozoic with terrane accretions and latest Mississippian 330 Ma-with arc magmatism, accretionary prism formation and thrusting. Indeed recent paleomagnetic reconstructions between the late Devonian and Mississippian show no subduction for approximately 30-20 million of years (Domeier and Torsvik, 2014). Coincidently, this lapse time is characterized by the intrusion of A-type granites in the foreland region (Dahlquist et al., 2006, 2010) and the formation of deep and isolated basins (Astini et al., 2011). On the base of this information, some interpretation have pointed out to extensional tectonics during the Mississippian (Astini et al., 2009, 2011; Grosse et al., 2009; Dahlquist et al., 2010, 2015; Martina et al., 2011; Alasino et al., 2012; Coira et al., 2016). However, few reports have described coeval structures and/or metamorphism for this time interval in agreement with the extensional setting.

In the Sierras Pampeanas of western Argentina (Fig. 1), NW-SE calc-alkaline lamprophyric dikes expose along the Famatina range for $>300 \mathrm{~km}$, intruding Ordovician granites and underlying Pennsylvanian to Permian beds (Turner, 1971; Villar Fabre et al., 1973; de Alba, 1979; Toselli et al., 1996; Dávila, 2003). Whole rock K-Ar

\footnotetext{
* Corresponding author.

E-mail address: fmartina@unc.edu.ar (F. Martina).
} 


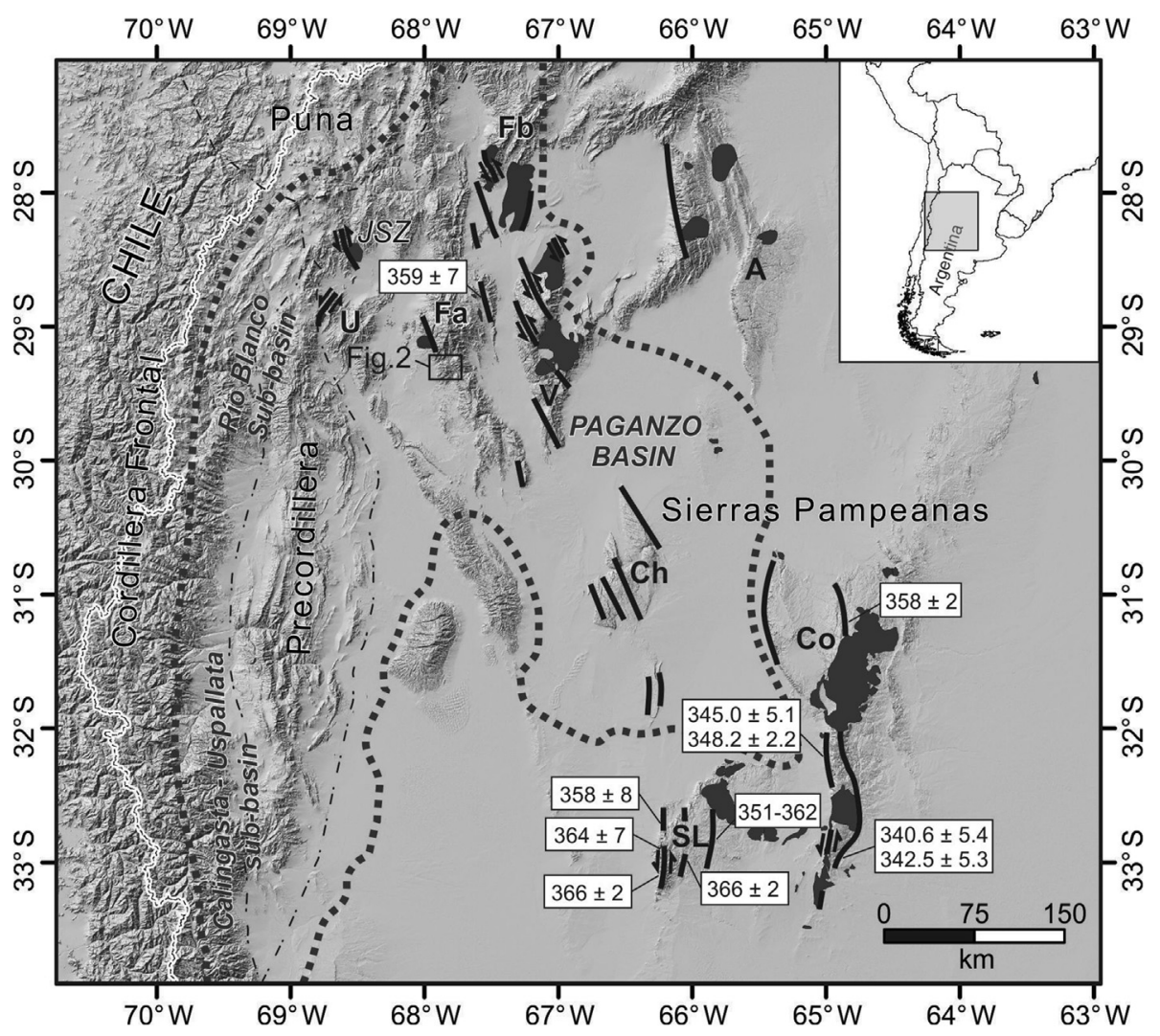

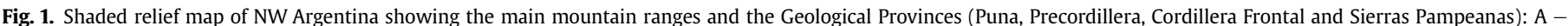

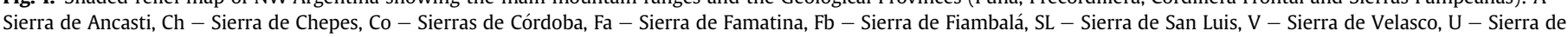

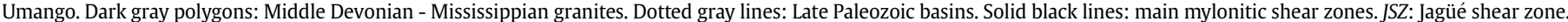

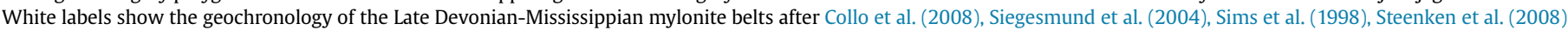
and Whitmeyer (2008). Notice the location of the study area (Fig. 2).

dating constrained them into the Silurian-Devonian, between $414 \pm 15 \mathrm{Ma}$ (Toselli, 1978) and 395 $\pm 20 \mathrm{Ma}$ (Villar Fabre et al., 1973 ). These ages, nevertheless, have large errors ( $>50 \mathrm{my}$ ), preventing accurate correlations with other coeval geological features toward conclusive interpretations about the tectonic significance of the igneous activity.

Lamprophyric dikes are usually associated with alkaline magmas, and have been used as evidence of extension/transtension tectonics (Vaughan, 1996; Tappe et al., 2006; Scarrow et al., 2011; Van der Meer et al., 2016). In fact, they have been locally related to the breakup of supercontinents such as Laurussia in the Jurassic (see Eby, 1987) or Gondwana in the Cretaceous (Van der Meer et al., 2016). Dike geometries and structures, in addition, are excellent evidences to study stress-strain relationships, giving insight of the regional paleostress regimes (Delaney et al., 1986; Glazner et al., 1999; Hou, 2012).

In this paper we report a new whole rock ${ }^{40} \mathrm{Ar} /{ }^{39} \mathrm{Ar}$ dating as well as structural measurements and kinematics analysis on lamprophyric dikes from the Famatina range, western Sierras Pampeanas. These studies assist us to establish correlations with other magmatic events recorded in western Argentina as well as to understand the deformation during the dike emplacement, in order to discuss likely tectonic scenarios during the Mississippian in SW Gondwana.

\section{Geological setting}

The Famatina range is a N-S mountain belt located between $27.5^{\circ}$ and $30^{\circ} \mathrm{S}$ and forms part of the Argentine broken foreland or
Sierras Pampeanas Province (Jordan and Allmendinger, 1986), a Miocene-Present Laramide-type region, where basement thrusting occurs to $>500 \mathrm{~km}$ from the modern trench (Fig. 1). The uplift of the pre-Cenozoic basement is associated with the transmission of deformation toward the distal foreland by slab flattening occurred at these latitudes, in the Central Andes, since the middle Miocene (Jordan et al., 1983; Kay and Mpodozis, 2002; Dávila et al., 2004). This basement thrusting was the main cause of the exhumation of Paleozoic rocks.

The stratigraphic framework of the Famatina range consists of thick Cambro-Ordovician clastic marine strata $(>1000 \mathrm{~s} \mathrm{~m})$ interbedded with bimodal volcanic layers (Astini and Dávila, 2004). Lower to Middle Ordovician I-type (Dahlquist et al., 2008) and Mississippian A-type granites (Dahlquist et al., 2010, 2015; Alasino et al., 2012) intrude the Lower Paleozoic successions (Fig. 2). While the Ordovician granites represent the subducted-driven margin of Gondwana during the Paleozoic (Terraustralis orogen; Cawood, 2005), the Mississippian granites constitute an anorogenic setting, though poorly studied (e.g., Dahlquist et al., 2010, 2015). In contrast to the other geological provinces to the west, north and east (Precordillera, Eastern Cordillera, Subandean belt and Chacoparana plain), no Silurian and Devonian geologic records have been described in the Sierras Pampeanas and Famatina range. Pennsylvanian (Upper Carboniferous) postglacial units to Permian red beds (Paganzo basin; Azcuy and Morelli, 1970) rest on different levels of Lower Paleozoic (Figs. 2 and 3a) indicative of deformation in the Famatina range during this time interval and possibly related to the collision of the Precordillera terrane in the Middle Ordovician (Astini and Dávila, 2004). Well-preserved and fine-grained 


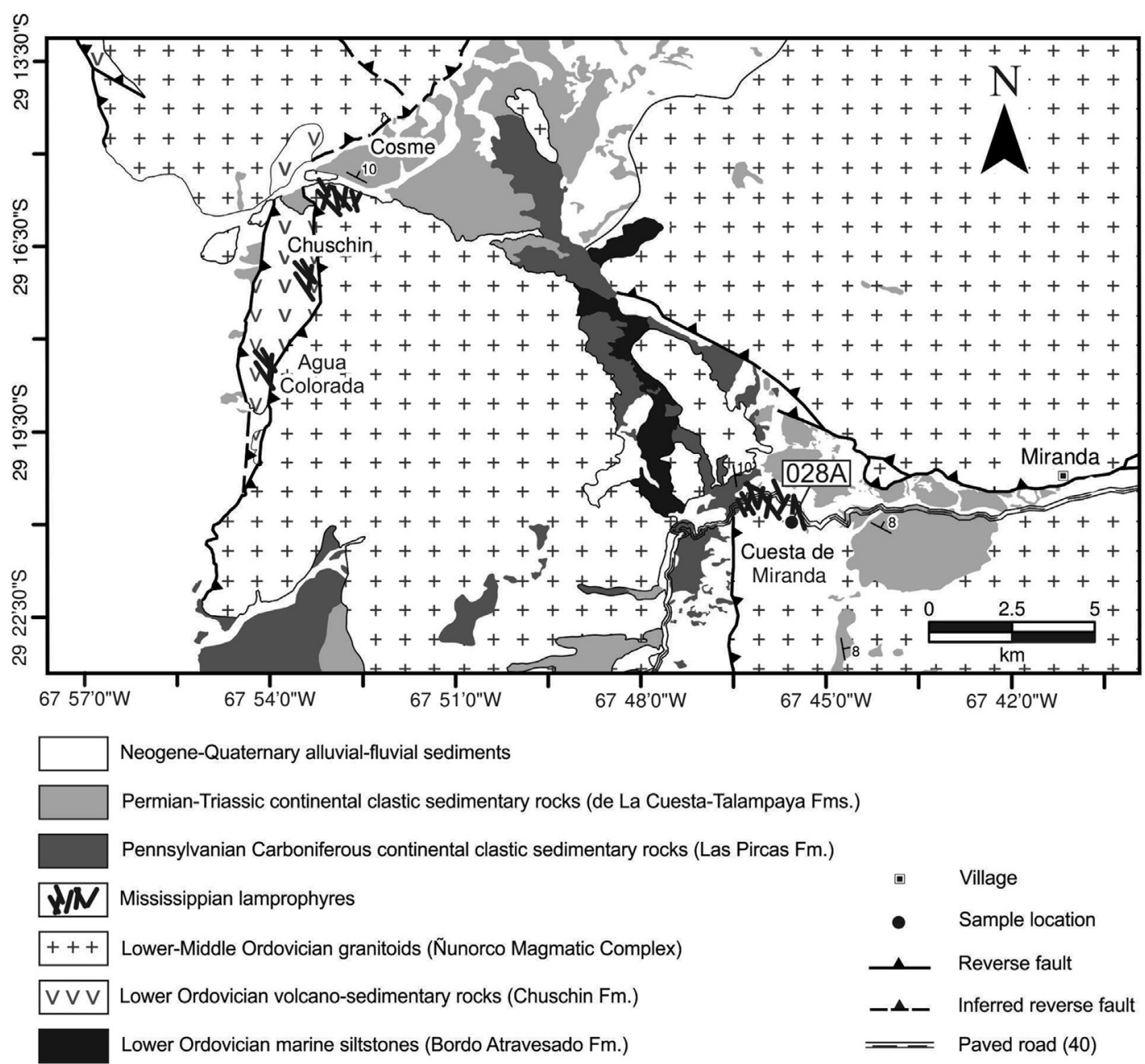

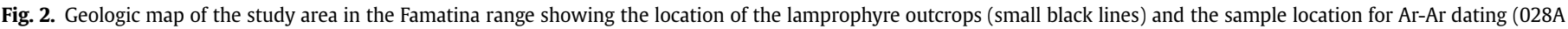
sample).

lamprophyric dikes (objective of this study) intrude the Ordovician basement (Fig. 3b) and are unconformably covered by the Carboniferous postglacial strata (Villar Fabre et al., 1973; Toselli et al., 1996).

It is important to mention that $100 \mathrm{~km}$ further west, in the northernmost Argentine Precordillera and southern Puna (Río Blanco basin, see location in Fig. 1), Mississippian shallow marine and subaqueous volcanic layers (Astini et al., 2011; Baez et al., 2014; Coira et al., 2016) are associated with isolated normal-fault basins (Fernández-Seveso and Tankard, 1995; Astini et al., 2011). These marine beds are coeval with the formation of continental glacial paleovalleys to the east (Isbell et al., 2012). Pennsylvanian ( 325 $\mathrm{Ma}$ ) glacial-postglacial beds, correlated with those exposed in the Famatina range, cover these disconnected "half grabens" (Astini et al., 2011), which might be used across western Argentina (and western Gondwana) as a marker horizon (Limarino et al., 2002; Gulbranson et al., 2010). The Pennsylvanian strata interfinger toward the main Cordillera, to the west, with arc-related igneous rock (Polanski, 1970; Koukharsky et al., 2009; Busquets et al., 2013), associated with the reestablishment of subduction along the Gondwana margin.

\section{Lamprophyre dike characteristics and structural features}

The lamprophyric dikes of the Famatina Range were initially mapped by Turner (1971) and Villar Fabre et al. (1973). The dikes are usually black to greenish gray, aphanitic and only the thickest dikes present plagioclase phenocrysts. The main mafic minerals are hornblende and biotite, although augites have also been observed as relict minerals, typical of lamprophyres. Except for local cases, the dikes are neither deformed nor metamorphosed. Our structural observations were focused on the Cosme, Chuschin and Cuesta de Miranda regions (Fig. 2), where spessartite and kersantite lamprophyre types are present (Villar Fabre et al., 1973; Toselli et al., 1996). However, they are recognized along the entire Famatina belt. Geochemically, the dikes are K-rich calcalkaline basalts and basaltic andesites with high $\mathrm{Cr}$, Co and $\mathrm{Ni}$ contents indicative of a primary origin (Toselli et al., 1996).

The dikes cut Ordovician granites (Ñunorco Magmatic Complex; Fig. $3 \mathrm{~b}$ and c) but locally intrude Lower Ordovician volcanosedimentary successions such as in the Chuschín and Agua Colorada river creeks (Armas et al., 2016; Conci et al., 2001; Mannheim, 1993). Pennsylvanian and Permian layers rest on the dikes and granites subhorizontally (dipping $<10^{\circ}$; Figs. 2 and $3 \mathrm{a}$ ). Although it is widely recognized the presence of a Middle Ordovician deformational event in the Famatina range that generated, among other structures, mylonitic belts affecting the granites (Astini and Dávila, 2004), in the studied sections there is no evidence of such planar anisotropy that could have controlled dike intrusion. The few pre-intrusion strata (Ordovician volcaniclastic units in the Chuschín creek) are roughly N- 

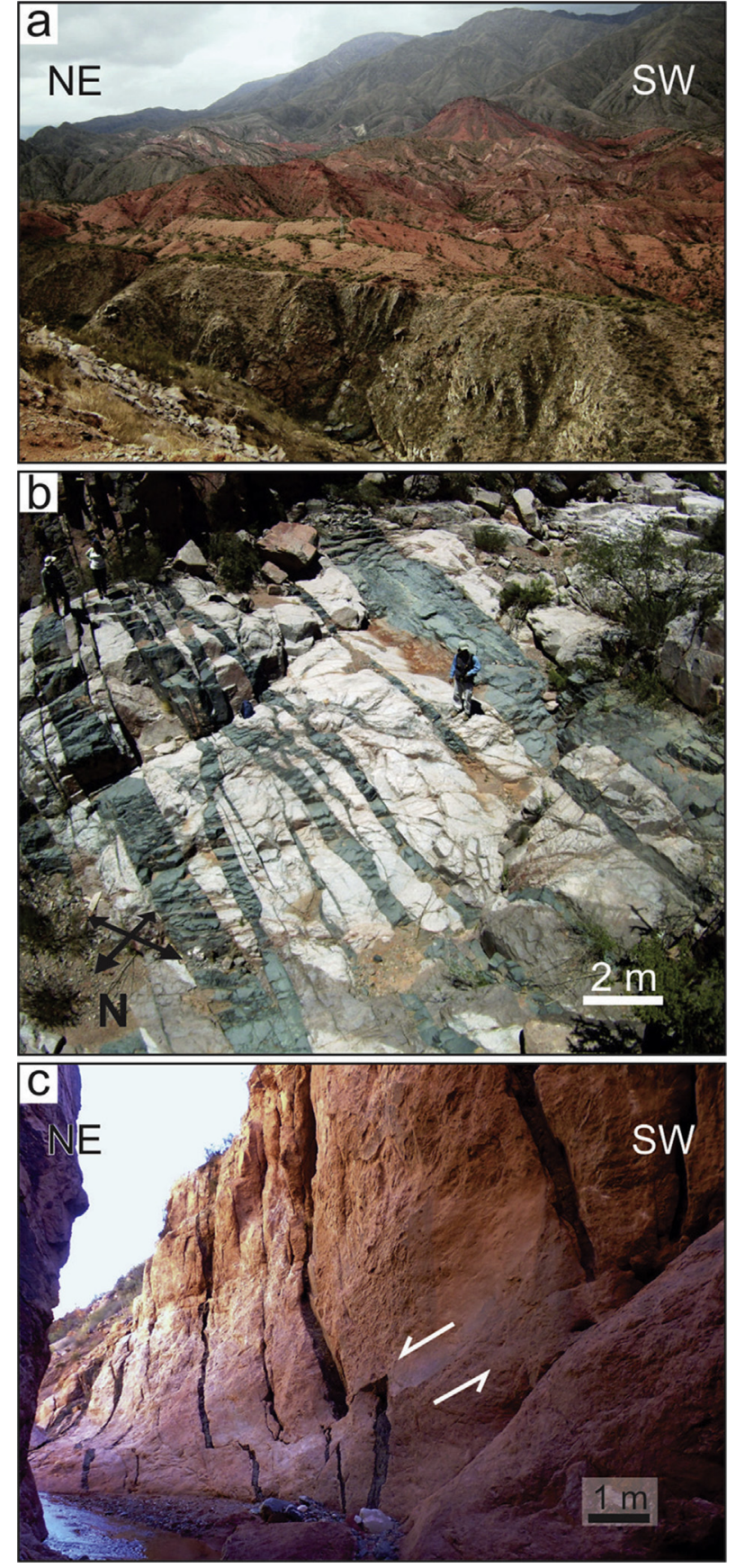

Fig. 3. Lamprophyric dike outcrops in the Famatina range. (a) Non-concordant contact between Permian red beds and Ordovician granites that host the studied dikes at Cuesta de Miranda. Note the subhorizontal arrangement of the Permian layers (see also orientations in Fig. 2). See the utility pole at the center of the picture as scale. (b) Subhorizontal view of NW trending dike swarm intruding the Ordovician granite at Cuesta de Miranda area. Notice the angular-shaped rafts of granite between adjacent dykes. (c) En-echelon lamprophyric dike arrays along the Cosme river creek indicating downdip (normal sense) displacements. Notice the continuity of some dikes along the fault zones whereas others are discontinue, which is indicative of the coeval development of tectonic activity and magmatism. (For interpretation of the references to colour in this figure legend, the reader is referred to the Web version of this article.)
S and steeply dipping both east and west. It is important to highlight that the only measured set of fractures that affect granites (N270 ${ }^{\circ}$ $290^{\circ} / 64^{\circ}-82^{\circ} \mathrm{NE}$ ) also cut the lamprophyres (N295 $/ 77^{\circ} \mathrm{NE}$ ), suggesting a post-emplacement deformation. Our structural analysis was conducted along transects mainly following river creeks, where 3D observations allowed more accurate kinematic analysis.

Lamprophyres crop out as isolated dike swarms, commonly over tens of bodies concentrated in a few hundreds of meters (Fig. 3b and c). They show a relatively constant NW-SE orientation along strike (average $\mathrm{N} 327^{\circ}$ ) and steeply $\left(>70^{\circ}\right)$ dipping to SW and NE. At the Cosme and Chuschín creeks the lamprophyric dikes have a mean trend of $\mathrm{N} 334^{\circ}$ (Fig. 4a) and dips ranging from $55^{\circ} \mathrm{NE}$ (average $79^{\circ} \mathrm{NE}$ ) to $84^{\circ} \mathrm{SW}$ (average $81^{\circ} \mathrm{SW}$; Fig. $4 \mathrm{~b}$ ) whereas to the south, at Cuesta de Miranda area, the dikes strike $\mathrm{N} 313^{\circ}$ (Fig. $4 \mathrm{a}$ ) and dip between $67^{\circ} \mathrm{SW}$ (average $76^{\circ} \mathrm{SW}$ ) and $68^{\circ} \mathrm{NE}$ (average $79^{\circ} \mathrm{NE}$; Fig. $4 \mathrm{~b}$ ). Restoration of data to pre-Permian conditions produces little modification to these values $(<2 \%$ ) and does not modify our interpretations (Fig. 4c). Similar values $\left(\mathrm{N} 330^{\circ} / 60^{\circ} \mathrm{E}\right)$ were described in northern Famatina range (Dávila, 2003), approximately $300 \mathrm{~km}$ northward from the study area. Locally, some conjugated subvertical dikes strike NE-SW (average $\mathrm{N} 59^{\circ}$ ). The measured dikes thickness ranges from 0.2 to $10 \mathrm{~m}$, but most are $<1.5 \mathrm{~m}$ wide. In most cases the dikes have tabular geometry and planar walls (Figs. 3 c and 5 a), although might show significantly thinned terminations. The contacts with the host granites are sharp and locally develops a thin $(<1-10 \mathrm{~cm})$ chilled zone (Fig. 5b). The dike frequency parameter (total number of dikes per kilometer measured perpendicular to the dike swarm orientation) along the Miranda river creek is 36 dikes $/ \mathrm{km}$, whereas in the Chuschín and Cosme areas it varies between 8 and 19 dikes $/ \mathrm{km}$, respectively, indicating a moderate density of the dike swarms. The sample chosen for dating comes from the Cuesta de Miranda region, where the dike density is high.

The fractures that host the lamprophyres (dike walls) show centimetric to metric offset margins both in cross-section and plan view, including en-echelon segmentation (continuous and discontinuous) with "bridges" of host rock (cf., Delaney and Pollard, 1981) and stepping geometries (Figs. $3 \mathrm{c}$ and $5 \mathrm{c}, \mathrm{d}$ ), as well as horns or bayonets structures (Fig. 5e). In the case of non-overlapping segments, the connection is through thin connectors or apophyses (Fig. 5c). Branches and rafts of host rocks are also common due to dikes coalescences (Fig. 3b). Sometimes the coalescence zone is displaced forming horns (Fig. 5d). While the NW dikes show a clear sinistral displacement across faults (Figs. 5d and 6a), the NE dikes report a dextral kinematics (Fig. $6 \mathrm{~b}$ ), such that the restitution of the dike walls requires an approximately $\mathrm{N} 15^{\circ}$ opening vector (Fig. 6c). This can also be recognized by matching markers across dike walls (Figs. 5a and 6a). In contrast, the dilation vector measured perpendicular to dike walls, trends NE-SW and differ from the opening vector by approximately $45^{\circ}$ (opening and dilation cf. Glazner et al., 1999), indicating a lateral component during dike emplacement. The vertical component indicates, in turn, down-dip movements consistent with a normal faulting (Figs. $3 c$ and $5 c$, e). A minimum upper crustal extension of $16.8 \%$ (ratio of present outcrop length, between the eastern and westernmost dikes, to initial length, calculated subtracting the present length to the sum of the dike width) was estimated for the Cuesta de Miranda region, following the Swanson (1992) methodology and the measured dike thickness and detailed mapping of Villar Fabre et al. (1973).

\section{Geochronology of the lamprophyre dikes}

\subsection{Sample description}

The analyzed sample (028A) corresponds to a subvertical $1.5 \mathrm{~m}$ thick lamprophyric dike that crops out in the Cuesta de Miranda region ( $29^{\circ} 20^{\prime} 48^{\prime \prime} \mathrm{S}-67^{\circ} 45^{\prime} 25^{\prime \prime} \mathrm{W}$ ) as part of a major dike swarm. 

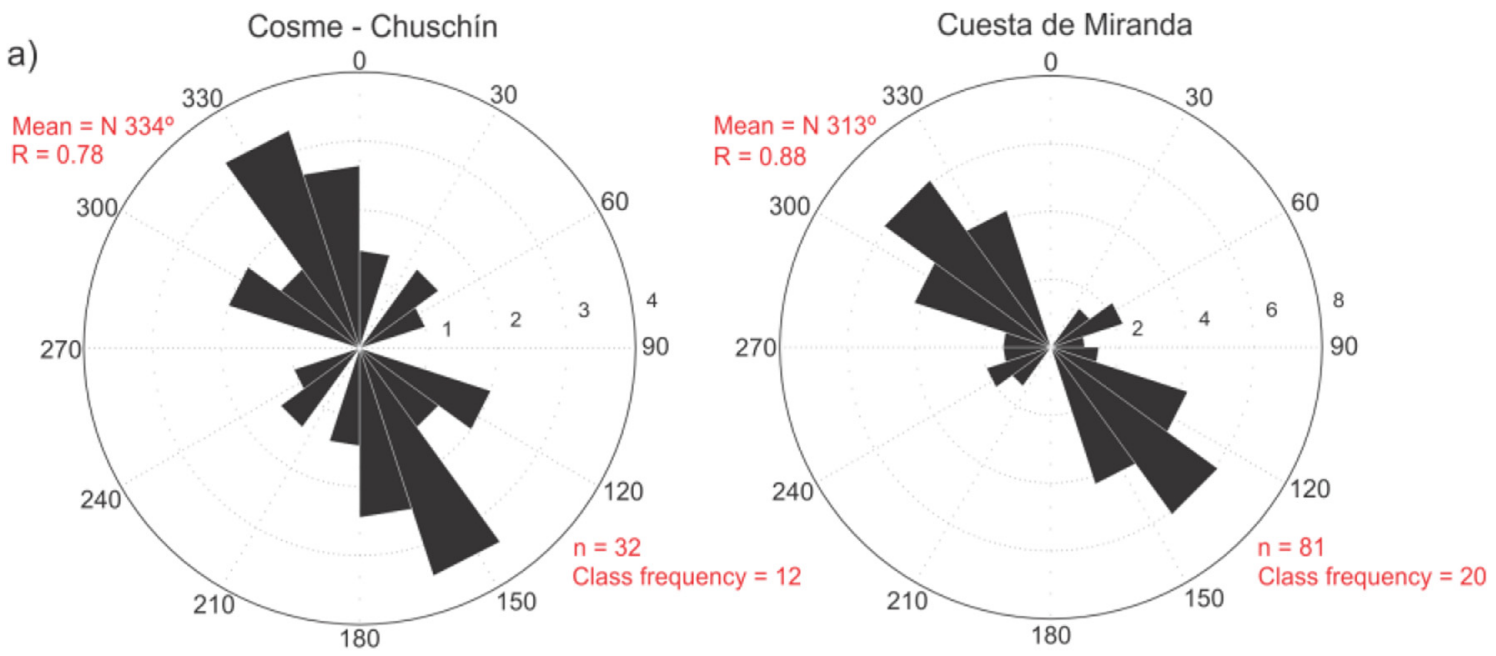

b)
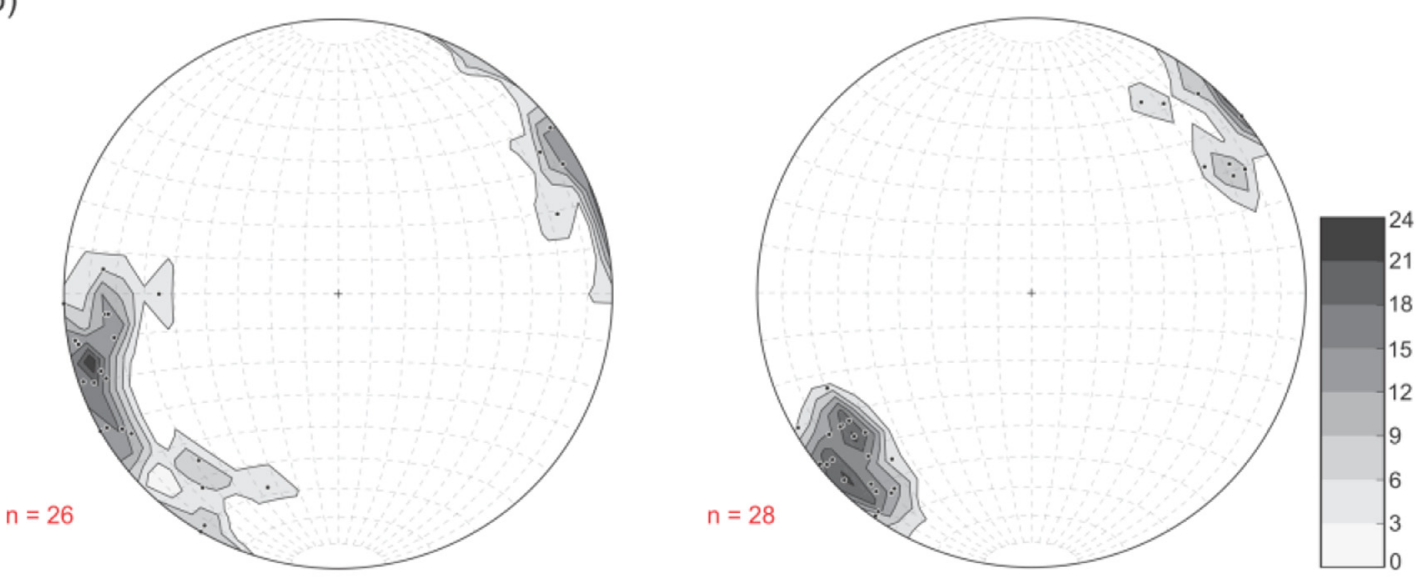

c)
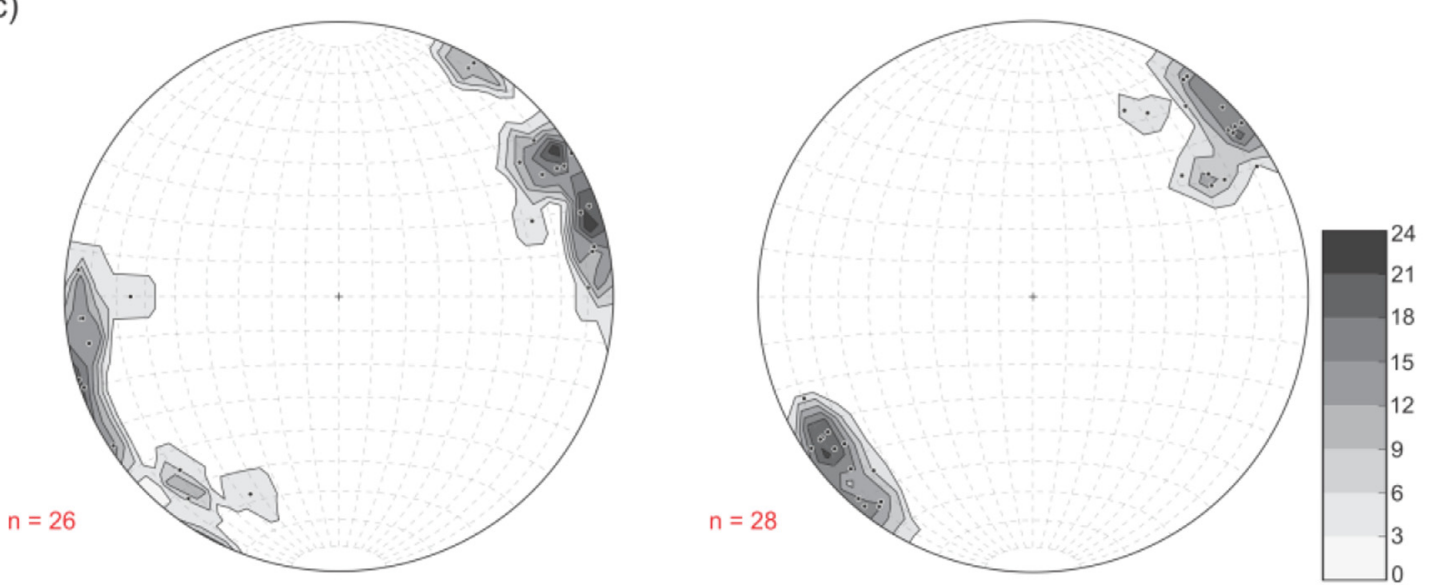

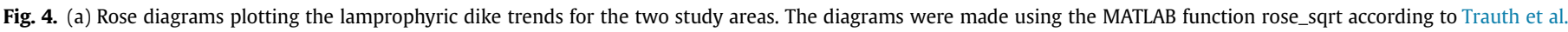

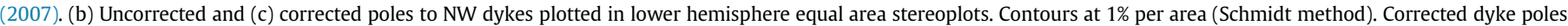

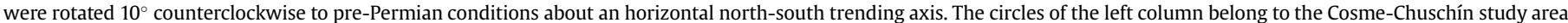
of and those of the right to the Cuesta de Miranda.

The lamprophyre is homogeneous, fine grained (aphanitic) and dark green. It shows no grain variations from the margins toward the center neither mixing with the host granite. The rock texture is equigranular and composed of strongly pleochroic green hornblendes (65\%), euhedral to subhedral plagioclase crystals (30\%) with corroded borders and opaque minerals (5\%). A minor presence of tremolite and biotite as halos around the mafic minerals was also observed. All these observations assist us to characterize the sample as pristine and fresh enough for dating purpose. Plagioclases show polysynthetic twinning and extinction angles between $26^{\circ}$ and $37^{\circ}$ indicating mainly labradorite compositions, according to the Michel Levy method. Some plagioclases also showed internal 

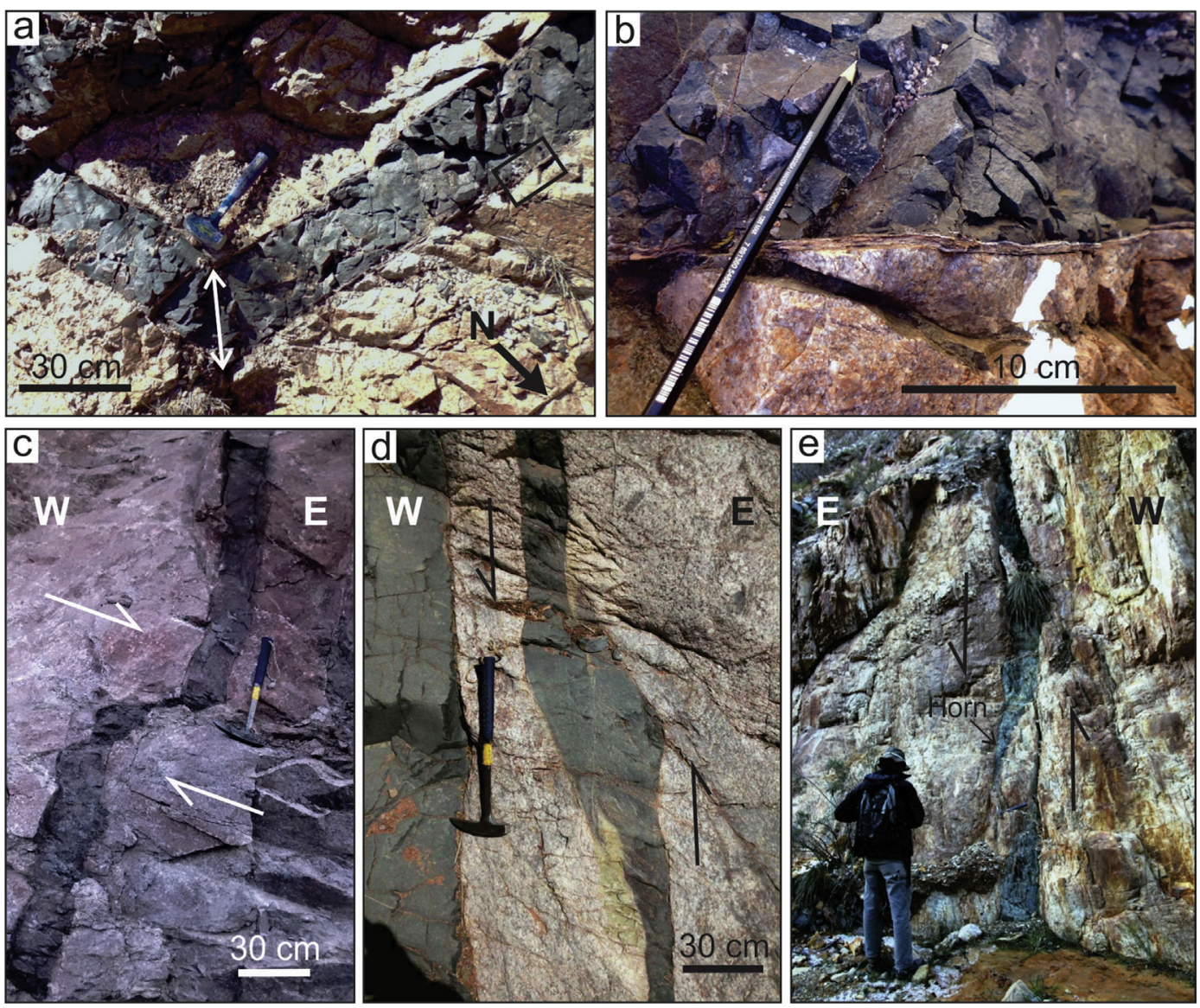

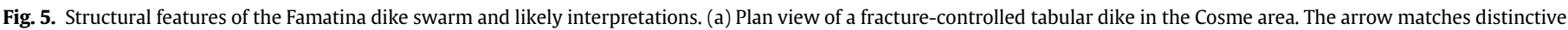

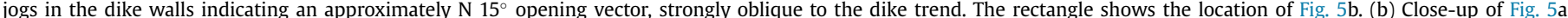

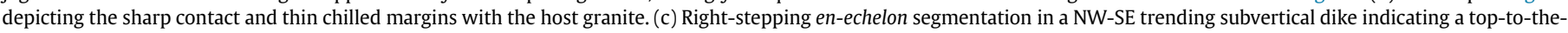

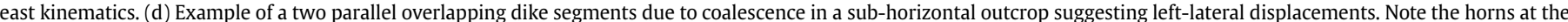

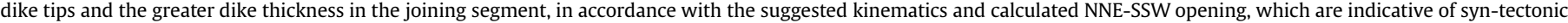
dike emplacement. (e) Lamprophyric dike in the Chuschín area showing horn structures, indicative of the normal faulting component during intrusion.

zoning with more strongly altered cores. The dating methodology is described in detail in Appendix A.

\section{2. ${ }^{40} \mathrm{Ar} /{ }^{39} \mathrm{Ar}$ results}

The plateau age and K/Ca spectrums of the sample 028A are depicted in Fig. 7 and the results are given in Table B.1 (Appendix B), including a full data report. Two aliquots of the irradiated whole rock sample fraction were progressively heated $0.1 \mathrm{~W}$ up to $1 \mathrm{~W}$ and then $0.2 \mathrm{~W}$ up to $3 \mathrm{~W}$ for 20 steps (A-T). However, only one aliquot produced a constant heating spectrum which yields a plateau age of $357.1 \pm 7.1 \mathrm{Ma}(\mathrm{MSWD}=2.3)$ including $57 \%$ of ${ }^{39} \mathrm{Ar}$ released $(\mathrm{G}-\mathrm{M}$ steps). The low variation of the $\mathrm{K} / \mathrm{Ca}$ ratio of the steps included in the plateau age calculation (Fig. 7) suggests that the hornblende was mostly involved rather than other subordinate mineral phases (low retentive phases for Argon), in accordance with the petrography. The $2 \sigma$ error of $2 \%$ is probably influenced by the small volume of ${ }^{40} \mathrm{Ar}$ released individually in each stage, which is about 30-50\% lower than the signal of the mass 40 of the air pipette. The normal isochron age is concordant at $352.2 \pm 5.8 \mathrm{Ma}(\mathrm{MSWD}=1.2)$, considering the same steps as the plateau age calculation. The integrated age is $346.3 \pm 5.5$ $\mathrm{Ma}$, which are very close to the plateau age considering the error bars.

We interpret our data as the crystallization age for the dike $028 \mathrm{~A}$ because there is no geological evidence in the region suggesting opening of the isotopic system and argon loss after the Mississippian. In this sense, the age of the metamorphism in Famatina is
Ordovician as documented by the $\mathrm{K}-\mathrm{Ar}$ ages of the lowmetamorphic grade basement where the Ordovician granites were intruded (Collo et al., 2008). In addition, published thermochronological data suggest that the region was never brought to depth after its early exhumation during the Mississippian (Jordan et al., 1989; Dávila and Carter, 2013). This is in agreement with the sedimentary nature of the Permian red beds that, in the studied sections, directly resting on the granitic country rock.

The ${ }^{40} \mathrm{Ar} /{ }^{39} \mathrm{Ar}$ plateau age for the lamprophyre dike in Famatina range is consistent with the stratigraphic position, cutting Ordovician granites and underlying Pennsylvanian beds, and younger and more precise than the previously obtained K-Ar whole rock ages ( $414 \pm 15$ and $395 \pm 20$ Ma, Toselli, 1978 and Villar Fabre et al., 1973 , respectively). Based on the new data we suspect that previous dating studies included an inherited mineral fraction that was excluded in our calculations from the step heating results.

\section{Discussion}

\subsection{Structural interpretation}

In the basement thrust sheets of the Famatina range, herein analyzed, the dikes were slightly tilted $\left(<10^{\circ}\right)$ after intrusion as indicated by the Pennsylvanian to Permian subhorizontal beds resting on granites and dikes (Fig. 3a). These relationships together with the systematic NW-SE orientation of the lamprophyres 
a)

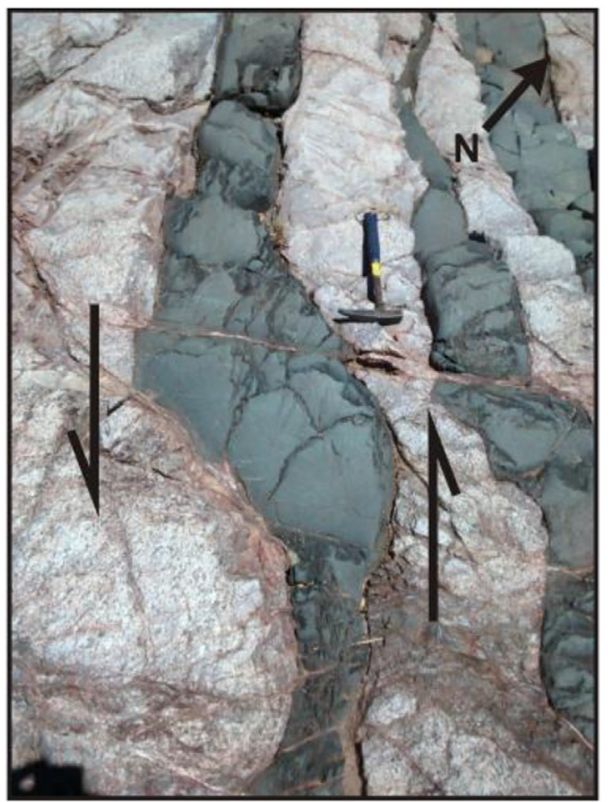

b)

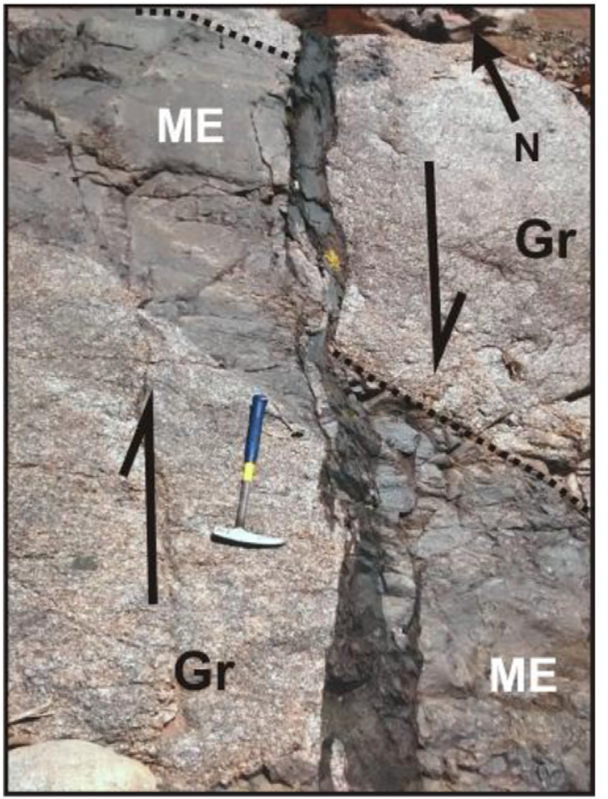

C)

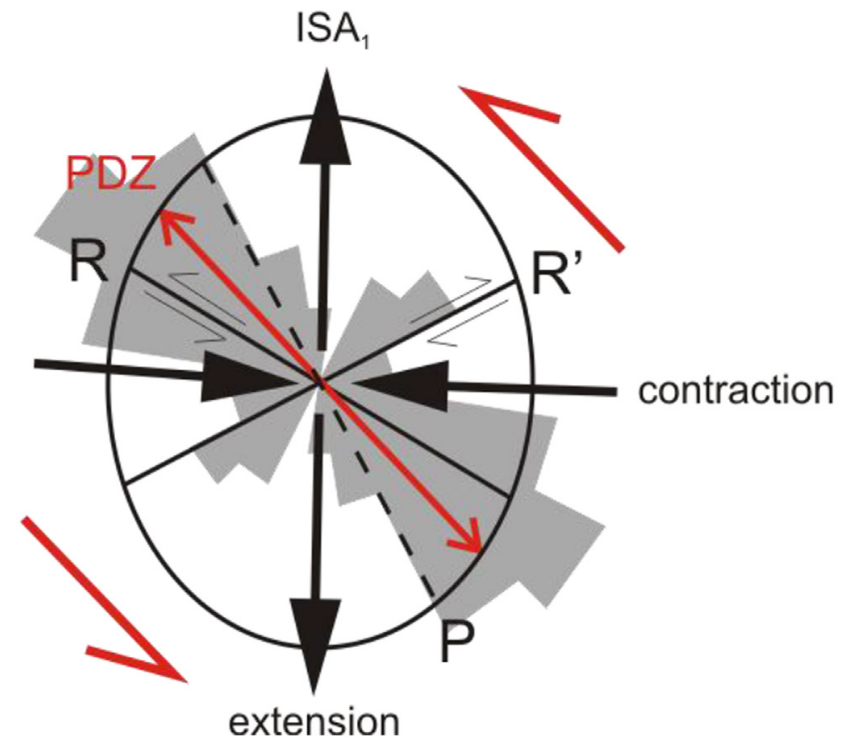

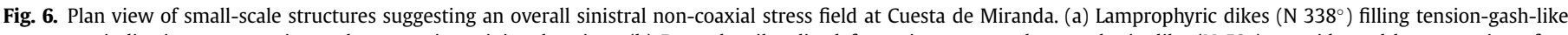

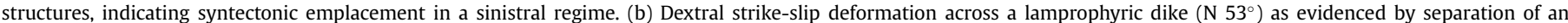

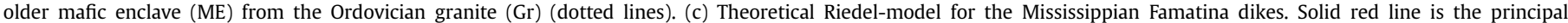

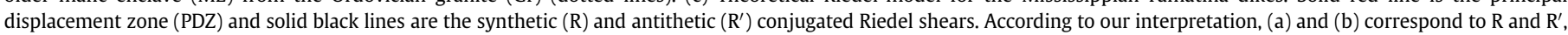

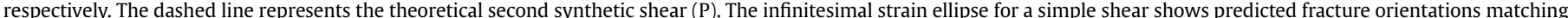

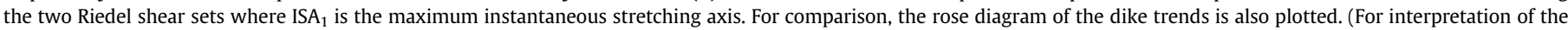
references to colour in this figure legend, the reader is referred to the Web version of this article.)

support the notion that intrusion was originally near-vertical. This interpretation agrees with AMS paleomagnetic data (Spagnuolo et al., 2008), which indicate a subvertical K1 principal axis. The sharp and thin contact zone of the Famatina lamprophyres suggests, in turn, shallow emplacement conditions, in accordance with the observed aphanitic texture.

The sub-parallel trending of most dikes, tabular geometry, planar walls and en echelon segmentation are all consistent with a strong structural control on dike intrusion (Delaney et al., 1986). Although we do not observed previous planar anisotropies controlling systematically the location of the dikes in the study area, we do not rule out the possibility in nearby regions. However, the presence of continuous and discontinuous offset dike geometries in the same cross-section (Fig. 3c) and the occurrence of little horns at the tips of sinistral displaced coalescent dikes in plan-view (Fig. 5d) are more consistent with syn-tectonic magmatism during the Mississippian. This deformation would have occurred before the dikes were completely solidified as indicated by the continuity of the dikes along the fault planes (Fig. $5 \mathrm{c}$ and d) and lack of solidstate fabrics in outcrops (Fig. 5a) and thin sections.

The interplay between magmatism and faulting has been widely addressed in the literature (Vaughan and Scarrow, 2003 and 


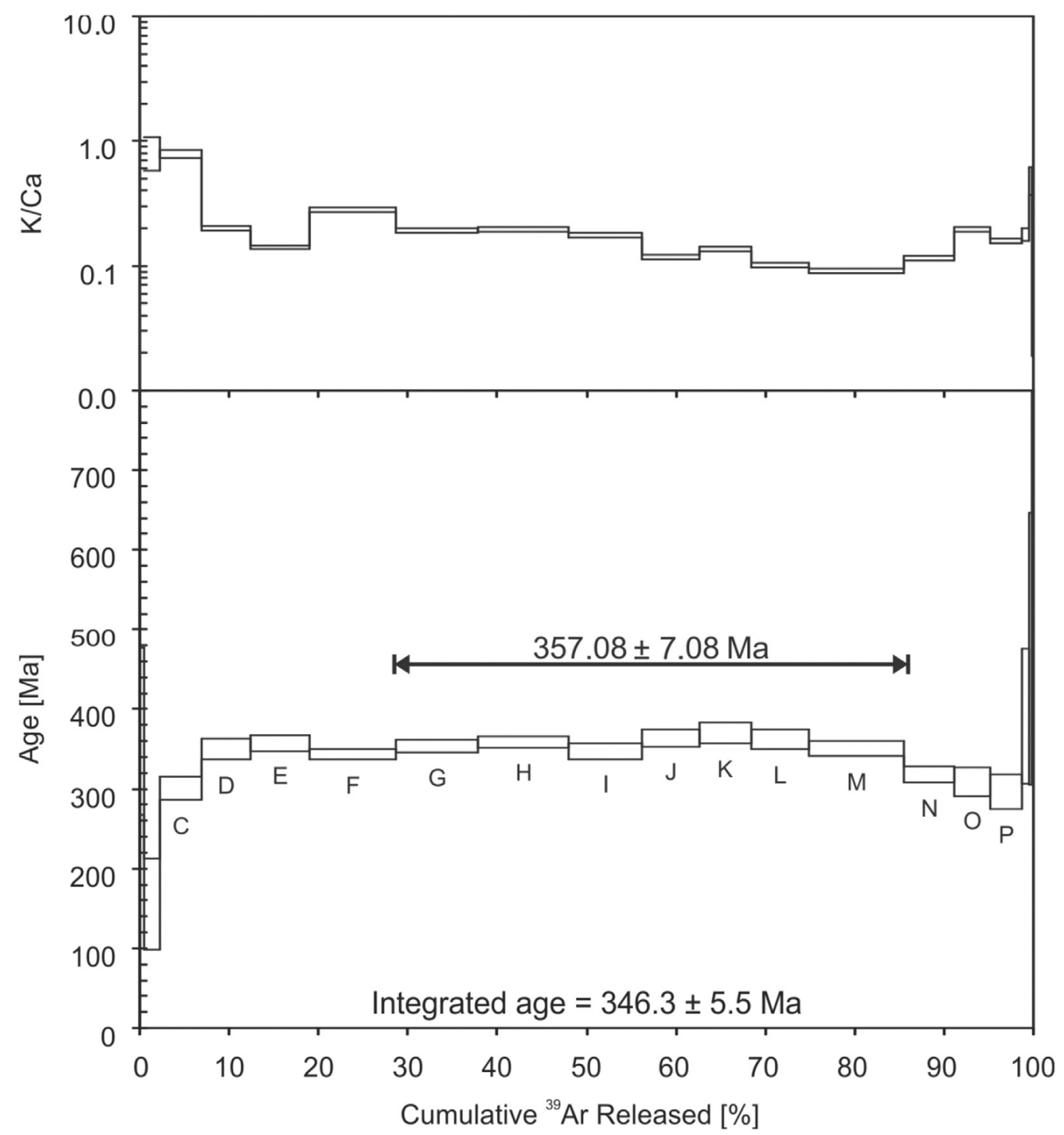

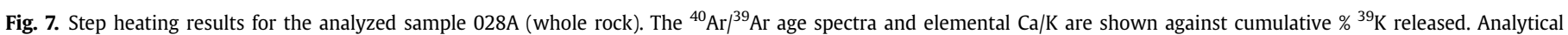
uncertainties (2-sigma) are represented by vertical width of scale bars.

references therein) and related to different tectonic settings (Cembrano and Lara, 2009). According to the Anderson model (1951), igneous dikes orientate perpendicular to the minimum stress direction $(\sigma 3)$. However, they might emplace obliquely to $\sigma 3$ when the magma intrusion: (1) occurred under non-coaxial finite strain conditions (e.g., shear zones), or (2) was injected along a preexisting fabric (Glazner et al., 1999; Ziv et al., 2000; Martinez-Poza et al., 2014), as channels for the ascending flow (non-Andersonian dikes). The kinematic indicators preserved in the Famatina dikes are more consistent with the former. As mentioned above, and in accordance with a non-coaxial deformation, the NW-SE orientation of the Famatina dikes evidences sinistral shearing, where the minimum principal stress axis $\left(\sigma_{3}\right)$ would orient NNE-SSW, oblique to the main dike trending (Figs. 5a and 6c). In addition, the stretching component observed in cross sections, and deduced from minor normal faults (Fig. 3c), suggests a bulk transtensional regime with top-to-the-north-northeast sense of shear.

A simple model to explain the structural features described above is to consider the lamprophyre dikes as Riedel fractures (Fig. 6c), where the NW-trending dikes would be the R shear and the NE-trending dikes the conjugate shears $\left(R^{\prime}\right)$ of the model (after Tchalenko, 1970). A Similar explanation has been proposed for the Caledonian (Vaughan, 1996) and Variscan (Scarrow et al., 2011) lamprophyres of Western Europe as well as for the Jurassic Independence dike swarm in the southwestern USA (Glazner et al., 1999). The $<45^{\circ}$ angular relationship between the NNWtrending $\mathrm{R}$ shear and the calculated theoretical primary shear is consistent with transtensional tectonics (cf., Rothery, 1988). The maximum modeled stretching direction (ISA or Instantaneous Stretching Axis) also coincides with the measured N-S opening vector (Fig. $6 \mathrm{c}$ ). The $\mathrm{R}^{\prime}$ shears are usually considered to be later to the formation of $\mathrm{R}$ shears (Sylvester, 1988). The Riedel-type fractures would have facilitated the mantle melts to flow to shallow crustal depths (see also Glazner et al., 1999; Scarrow et al., 2011; Van der Meer et al., 2016), as suggested for the Famatina dikes.

Although most observations and interpretations point out to a syntectonic dyke emplacement, we do not discard that pre-existing sub-parallel fracture systems, generated between the exhumation of Ordovician-Silurian mylonites (reported in the region) and granites and the intrusion of Mississippian lamprophyres intrusion, served as fluid conducts. 
5.2. Mississippian stretching along western Gondwana: continental rifting or accommodation zone?

\subsubsection{Regional evidences}

The field observations and measurements on $>100$ Famatina lamprophyric dikes as well as on the structure of surrounding country rocks (walls and fractures) suggest that the 354 Ma dike intrusion would have occurred under sinistral transtensional to moderate extensional $(\sim 17 \%)$ regimes, likely associated to normal faulting systems with strong strike-slip components.

The transtensional tectonic setting interpreted in this contribution is consistent with both the geochemical data of nearby Mississippian A-type granites and associated alkaline volcanics that indicate extensional emplacement into the lithosphere (Dahlquist et al., 2010; Alasino et al., 2012; Coira et al., 2016) and with coetaneous development of rift-type or pull apart basins (Los Llantenes Formation in the northernmost Precordillera, Astini et al., 2011). The structural control on the Late Devonian - Mississippian magmatism in western Gondwana was previously suggested to explain the emplacement of the A-type granites in the Sierras Pampeanas province (Pinotti et al., 2002; Höckenreiner et al., 2003; Dahlquist et al., 2010). According to Dahlquist et al. (2010), the granites were injected along pre-existing shear zones that facilitated magma ascent and emplacement at shallow crustal levels. Shear sense indicators suggest sinistral strike-slip movements along some of these belts during the Late Devonian-Mississippian times (López, 2005; Pinotti et al., 2014). In fact, the scattered distribution and low volume of the Mississippian magmatism in western Gondwana would be more consistent with a transtensional tectonic model rather than pure extension or simple shear, where the releasing bends of the strike-slip system may have played a major role in the granite emplacement (e.g., Tikoff and Teyssier, 1992; Corti et al., 2003). The poor deformation and subcircular geometry of the granites agree with this interpretation.

The lamprophyre dike emplacement through transtensional shear zones during the Mississippian in the Famatina range is likely not a single and local case in western Gondwana. Other similar NNW-SSE shear zones assigned to this time lapse were described in the Sierras Pampeanas province (in the Sierra de San Luis by Siegesmund et al., 2004; Whitmeyer and Simpson, 2004; and NW Sierra de Umango by Meira et al., 2012). We neither disregard a correlation with the Jague slip zone, located between the northernmost Precordillera and the Sierras Pampeanas, which records a similar sinistral kinematics and precise deformation timing is uncertain (Martina and Astini, 2009, Fig. 1). This shear zone affects Precambrian-Lower Paleozoic basement rocks and is overlaid by undeformed Upper Mississippian beds. This time interval is when the lamprophyric dikes intruded in the Famatina range.

It is important to notice that Whitmeyer and Simpson (2004) proposed Middle to Late Devonian left-lateral tectonics in the Eastern Sierras Pampeanas, along the western margin of Gondwana. Although these authors related this tectonic event to the collision of the Chilenia terrane, new geochronological data on mylonites allowed constraining the age of the deformation to the latest Devonian-Mississippian (ca. 360 Ma.; Steenken et al., 2008; Whitmeyer, 2008). This age is similar to the intrusion time of the Famatina lamprophyric dikes and 35 Ma younger than the proposed collision of Chilenia (ca. 390 Ma., cf. Willner et al., 2011).

\subsubsection{Continental inferences}

Most recent Mississippian tectonic models of southwestern Gondwana are mainly based on igneous geochemistry that has to explain two contrasted settings. While A-type granite intrusions occurred cratonward (Dahlquist et al., 2006, 2010, 2015; Grosse et al., 2009; Alasino et al., 2012), Mississippian lamprophyres dikes developed in the Famatina range (described in this work) and subaqueous bimodal volcanism were reported westward in the northernmost Precordillera and the southernmost Puna region (Martina et al., 2011; Baez et al., 2014; Coira et al., 2016). Most of these studies proposed regional lithospheric extension operating conditions (Grosse et al., 2009; Dahlquist et al., 2010, 2015; Alasino et al., 2012; Coira et al., 2016). The main difference among these models is the mechanism that produced extension: (i) postorogenic extension (relaxation) after the alleged Chilenia terrane collision in the Middle Devonian (Willner et al., 2011) or, more recently, (ii) slab rollback following a stage of flat subduction (Alasino et al., 2012). However, as stated above, there are no compelling evidences for an orogen and subduction until the latest Mississippian - Early Pennsylvanian times, when a complete arctrench system was installed such as documented in western Chile (del Rey et al., 2016), after a transitional period (between two clear subduction phases) characterized by marine sedimentation from the Silurian to Middle Devonian (Bahlburg and Hervé, 1997; Bahlburg et al., 2009).

Based on our structural data, and those compiled from the literature referring to regional deformation, we propose an alternative transtensional model that allows combining most of the Mississippian geological record, in agreement with the contemporaneous global tectonics. This constitutes a likely hypothesis for future work.

Gondwana was positioned in the South Pole during the Middle Paleozoic to Mississippian, and Western Gondwana occupied, in turn, the most external ring (Torsvik and Cocks, 2013). It was limited by continental transforms and no subductions were proposed for this time period (Fig. 8). During the lamprophyre intrusion in Famatina (herein dated at $357.1 \pm 7.1 \mathrm{Ma}$ ), the supercontinent would have underwent $\sim 20^{\circ}$ counterclockwise rotation without significant translation (Fig. 8), as evidenced by paleomagnetic reconstructions (Domeier and Torsvik, 2014). It is intriguing to speculate that the Famatina dikes may, in some way, be related to this rotational deformation, causing friction and torsion along the western margin of Gondwana, which would have generated the fabric and fractures to emplace the mantle fluids to shallow crustal levels. A similar explanation has been suggested for the Jurassic Independence dike swarm of western USA (Wolf and Saleeby, 1995) and Western Antarctica from the late Cenozoic to the present (see Rocchi et al., 2003; Faccenna et al., 2008). According to our interpretation, the left-lateral strike-slip tectonics recorded in western Argentina might have accommodated the relative displacement between individual basement blocks likewise those reported in different regions of Sierras Pampeanas (Fig. 1). Such decoupling of the continent during rotation would be result of different displacement from the border of the continent (maximum) toward the rotation pole (zero). These accommodation strike-slip faults likely took advantage of previous suture zones such as those associated with the collision and amalgamation of Western Gondwana during the Proterozoic and Early Paleozoic.

Finally our preliminary model does not require of a transform plate boundary along SW Gondwana to work, but rather needs a very oblique movement along the continental margin in order to support the left-lateral strike slip tectonics. Therefore, a strongly oblique subduction could also generate the stress field required by the Famatina dikes.

\section{Conclusions}

1. Our field work observations show a strong structural control during the emplacement of the lamprophyric dikes in the Famatina range (Argentina), evidenced by the NW orientation, en echelon segmentation, tabular geometries and flat walls. 

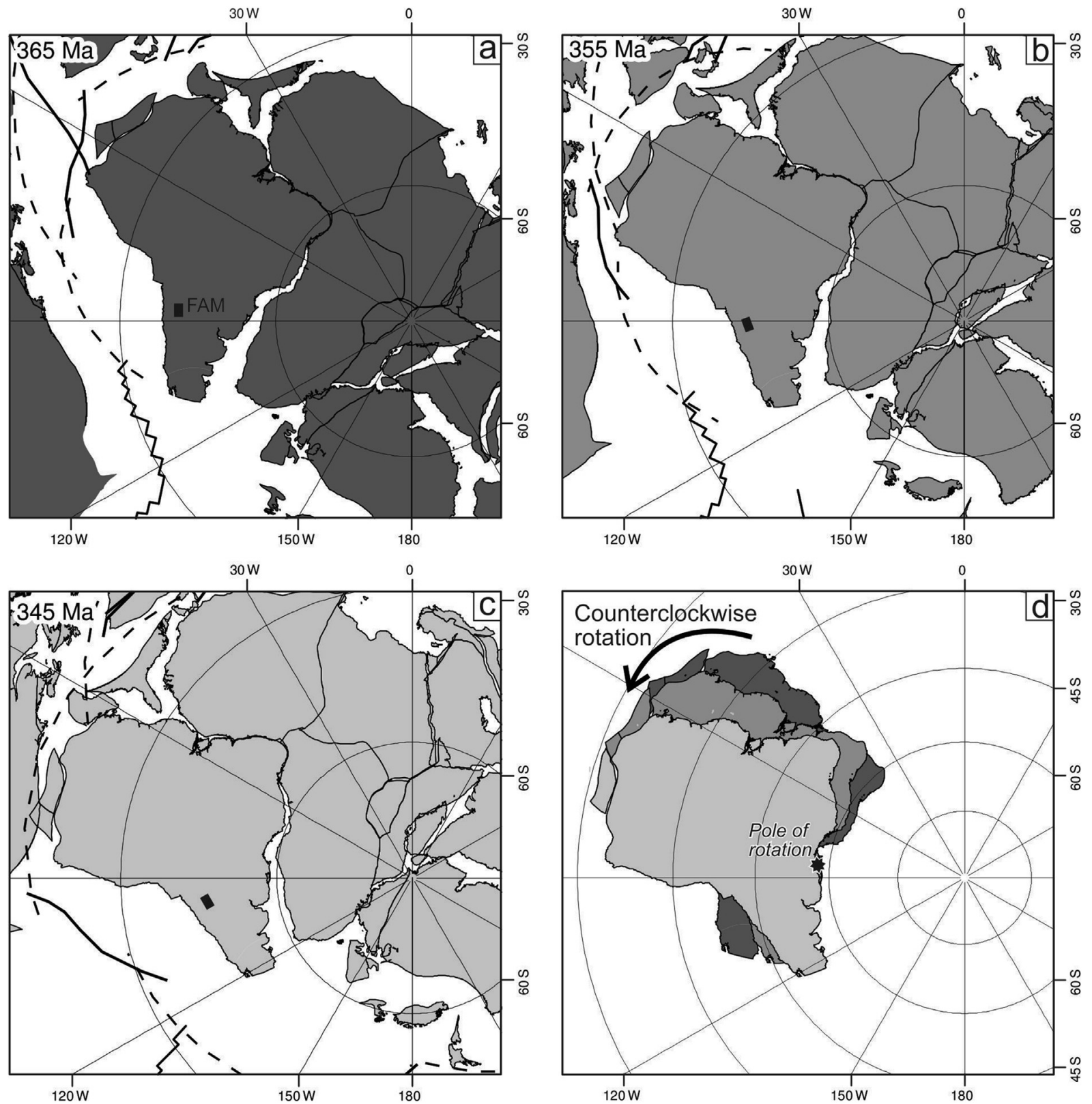

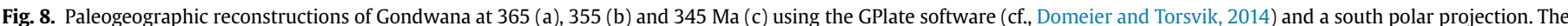

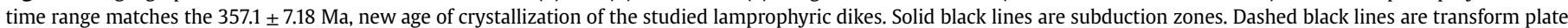

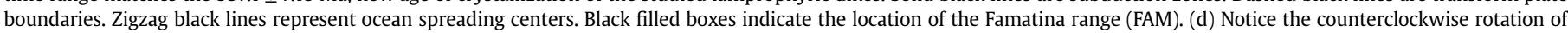

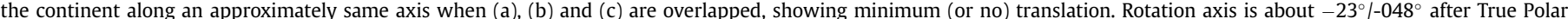
Wander correction (Domeier, pers. comm.). See text for details.

Distribution pattern indicated dikes followed Riedel fracture systems.

2. Whole rock ${ }^{40} \mathrm{Ar} /{ }^{39} \mathrm{Ar}$ geochronology of a lamprophyric sample from Cuesta de Miranda study area yielded a plateau age of $357.1 \pm 7.1 \mathrm{Ma}$, which is younger than previously reported $\mathrm{K}-\mathrm{Ar}$ ages for similar dikes.

3. The kinematic indicators suggest a left-lateral transtensional tectonics consistent with coeval A-type magmatism, half graben-type sedimentation and strike-slip shear zones reported along west-central Argentina by other authors.

4. We propose that a transtensional field resulted from the counterclockwise fast rotation of Gondwana between 365 and 345 Ma. Such rotation was internally accommodated by the relative sinistral displacement between basement blocks across the western margin of the supercontinent, favoring the lamprophyric dikes emplacement at $\sim 360 \mathrm{Ma}$.

5. Our interpretation does not require the development of subduction along the western margin of Gondwana, in agreement with the Domeier and Torsvik, 2014 paleomagnetic model, which proposes a transform boundary and net rotation (with little translation) during the Mississippian, when the studied lamprophyres emplaced in the Famatina range.

\section{Acknowledgements}

We thank CONICET (particularly PUE 2016 CICTERRA), UNC 
SECyT 313/16, FONCYT PICT-2015-1092 and MINCyT/CAPES BR 1306 (Argentina-Brazil) program for funding support. L. Gilli assisted with sample preparation and R. Siqueira with ${ }^{40} \mathrm{Ar} /{ }^{39} \mathrm{Ar}$ geochronology. H.C. is also thanked to Dr. Echeveste and his students at the Universidad Nacional de la Plata for their suggestions and assistance during field work. Constructive reviews by Dr. Hongn and Dr. Leal significantly improved the final version of the manuscript.

\section{Appendix A. Ar-Ar methodology}

The ${ }^{40} \mathrm{Ar} /{ }^{39} \mathrm{Ar}$ geochronology was carried out at the Centro de Pesquisas Geocronologicas (CPGeo) of the Universidad de Sao Paulo, Brazil, using the ArArCalc free data reduction program (Koppers, 2002). The lamprophyre sample was crushed and then powdered using an automatic agate mortar in the LABGEO (CICTERRA and Universidad Nacional de Córdoba) to reach a grain size between 200 and $500 \mu \mathrm{m}$. A selected amount of the sample was irradiated with epithermal neutrons for 15 continuous hours in the CLICIT facility of the Oregon State University TRIGA reactor, along with the Fish Canyon sanidine standard $(28.01 \pm 0.04 \mathrm{Ma}$; Phillips and Matchan, 2013). After a period of cooling, the irradiated sample was loaded for step heating analysis via solid-state Nd laser $\mathrm{YVO}_{4}$ (532 nm - Verdi $6 \mathrm{~W}$ Coherent model). The laser extraction system is coupled to a purification system running with getters (SAES-GP50) and to a multicollector ARGUS VI mass spectrometer. The argon masses 40-36 were measured simultaneously in $5 \mathrm{~F}$ collectors $\left(10^{11} \Omega\right.$ for the ${ }^{40} \mathrm{Ar}$, and $10^{12} \Omega$ for the other argon masses). Mass discrimination was monitored by analysis of air pipettes $\left({ }^{40} \mathrm{Ar} /{ }^{36} \mathrm{Ar}\right.$ weighted mean $\left.=298.5\right)$. The apparent ages were calculated at each heating step using a factor $\mathrm{J}=0.00423 \pm 0.00003$ and the decay constant values of Min et al. (2000), after corrections for mass discrimination, nucleogenic interferences and atmospheric argon. The criterion followed to define a plateau age is the identification of three or more successive steps overlapping with an error at $2 \sigma$ level that together comprise $>50 \%$ of ${ }^{39} \mathrm{Ar}$ released. All final age results are reported with $2 \sigma$ uncertainties.

\section{Appendix B. Supplementary data}

Supplementary data related to this article can be found at https://doi.org/10.1016/j.jsames.2018.02.006.

\section{References}

Alasino, P.H., Dahlquist, J.A., Pankhurst, R.J., Galindo, C., Casquet, C., Rapela, C.W., Fanning, C.M., 2012. Early Carboniferous sub-to mid-alkaline magmatism in the Eastern Sierras Pampeanas, NW Argentina: a record of crustal growth by the incorporation of mantle-derived material in an extensional setting. Gondwana Res. 22 (3), 992-1008.

Anderson, E.M., 1951. The Dynamics of Faulting and Dyke Formation with Application to Britain, second ed. Oliver \& Boyd, Edinburgh.

Armas, P., Cristofolini, E., Otamendi, J., Tibaldi, A., Barzola, M., 2016. Caracterización de las facies volcano-sedimentarias de la Formación Chuschín, sector surOccidental del sistema de Famatina, provincia de la Rioja. Rev. Asoc. Geol. Argent. 73 (1), 78-92.

Astini, R.A., Dávila, F.M., 2004. Ordovician back-arc foreland and Ocloyic thrust belt development on the western Gondwana margin as a response to Precordillera terrane accretion. Tectonics 23 (4).

Astini, R.A., Martina, F., Ezpeleta, M., Dávila, F.M., Cawood, P.A., 2009. Chronology from rifting to foreland basin in the Paganzo basin (Argentina), and a reappraisal on the "Eo-and neohercinian" tectonics along the western Gondwana. XII congreso geológico chileno. Ext. Abstr. S9-010, 1-4.

Astini, R.A., Martina, F., Dávila, F.M., 2011. The Los Llantenes Formation in the Precordillera of Jagüé (La Rioja province) and the recognition of a rifting stage in the early evolution of the Late Paleozoic basins in western Argentina. Andean Geol. 38 (2), 245-267.

Azcuy, C., Morelli, J.R., 1970. The Paganzo Basin: tectonic and sedimentary characteristics of the Gondwana sequences in northwestern Argentina. In: $2^{\circ}$ Gondwana Symposium, pp. 241-247 (South Africa).

Baez, W., Astini, R., Ezpeleta, M., Martina, F., 2014. Facies volcaniclásticas y paleoambiente sedimentario de la Formación Punta del Agua, carbonífero temprano de la Precordillera Septentrional, La Rioja. Rev. Asoc. Geol. Argent. 71 (2), 210-232.

Bahlburg, H., Hervé, F., 1997. Geodynamic evolution and tectonostratigraphic terranes of northwestern Argentina and northern Chile. Geol. Soc. Am. Bull. 109 (7), 869-884.

Bahlburg, H., Vervoort, J.D., Du Frane, S.A., Bock, B., Augustsson, C., Reimann, C. 2009. Timing of crust formation and recycling in accretionary orogens: insights learned from the western margin of South America. Earth Sci. Rev. 97 (1-4) $215-241$.

Busquets, P., Limarino, C.O., Cardó, R., Méndez-Bedia, I., Gallastegui, G., Colombo, F. Heredia, N., Césari, S.N., 2013. El neopaleozoico de la sierra de castaño (Cordillera Frontal Andina, San Juan, Argentina): reconstrucción tectónica y paleoambiental. Andean Geol. 40 (1), 175-195.

Cawood, P.A., 2005. Terra australis orogen: rodinia breakup and development of the pacific and iapetus margins of Gondwana during the neoproterozoic and paleozoic. Earth Sci. Rev. 69 (3-4), 249-279.

Cembrano, J., Lara, L., 2009. The link between volcanism and tectonics in the southern volcanic zone of the Chilean Andes: a review. Tectonophysics 471 (1-2), 96-113.

Coira, B., Cisterna, C., Ulbrich, H., Cordani, U., 2016. Extensional carboniferous magmatism at the western margin of Gondwana: las lozas valley, catamarca, Argentina. Andean Geol. 43 (1), 105-126.

Collo, G., Astini, R.A., Cardona, A., Do Campo, M.D., Cordani, U., 2008. Edades de metamorfismo en las unidades con bajo grado de la región central del Famatina: La impronta del ciclo orogénico oclóyico (Ordovícico). Rev. Geol. Chile 35 (2), 191-213.

Conci, I.D., Dávila, F.M., Astini, R.A., Martino, R.D., 2001. La. In: Faja de deformación de Chuschín (29॰17' S), Sierra de Famatina, Provincia de La Rioja, vol. 5. Asociación Geológica Argentina, Special Publication, Argentina, pp. 117-120.

Corti, G., Bonini, M., Conticelli, S., Innocenti, F., Manetti, P., Sokoutis, D., 2003. Analogue modelling of continental extension: a review focused on the relations between the patterns of deformation and the presence of magma. Earth Sci. Rev. 63 (3-4), 169-247.

Dahlquist, J.A., Pankhurst, R.J., Rapela, C.W., Casquet, C., Fanning, C.M., Alasino, P., Baez, M., 2006. The san blas pluton: an example of carboniferous plutonism in the Sierras Pampeanas, Argentina. J. S. Am. Earth Sci. 20 (4), 341-350.

Dahlquist, J.A., Pankhurst, R.J., Rapela, C.W., Galindo, C., Alasino, P., Fanning, C.M. Saavedra, J., Baldo, E., 2008. New SHRIMP U-Pb data from the Famatina Complex: constraining early-mid ordovician famatinian magmatism in the Sierras Pampeanas, Argentina. Geol. Acta 6 (4), 319-333.

Dahlquist, J.A., Alasino, P.H., Eby, G.N., Galindo, C., Casquet, C., 2010. Fault controlled Carboniferous A-type magmatism in the proto-Andean foreland (Sierras Pampeanas, Argentina): geochemical constraints and petrogénesis. Lithos 115 (1-4), $65-81$.

Dahlquist, J.A., Alasino, P.H., Morales Cámera, M.M., 2015. Petrografía, química mineral y geoquímica comparada de los plutones potrerillos y cerro la gloria: magmatismo de arco y retroarco en el carbonífero inferior. Rev. Asoc. Geol. Argent. 72 (2), 167-181.

Dávila, F.M., 2003. Transecta estratigráfica-estructural a los 28`30’-2854' de Latitud Sur, sierra de Famatina, provincia de La Rioja, República Argentina. PhD thesis. Universidad Nacional de Córdoba, p. 518.

Dávila, F.M., Carter, A., 2013. Exhumation history of the Andean broken foreland revisited. Geology 41 (4), 443-446.

Dávila, F.M., Astini, R.A., Jordan, T.E., Kay, S.M., 2004. Early Miocene andesite conglomerates in the Sierra de Famatina, broken foreland region of western Argentina, and documentation of magmatic broadening in the south Centra Andes. J. S. Am. Earth Sci. 17 (2), 89-101.

Davis, J.S., Roeske, S.M., McClelland, W.C., Snee, L.W., 1999. Closing the ocean between the Precordillera terrane and Chilenia: early devonian ophiolite emplacement and deformation in the SW Precordillera. In: Ramos, V.A. Keppie, J.D. (Eds.), Laurentia-Gondwana Connections before Pangea. Geological Society of America Special Paper, vol. 336, pp. 115-138.

de Alba, E., 1979. Descripción geológica de la hoja 16d, Chilecito: provincia de La Rioja: carta geológico-económica de la República Argentina. Escala 1, 200, 000. Servicio Geológico Nacional.

del Rey, A., Deckart, K., Arriagada, C., Martínez, F., 2016. Resolving the paradigm of the late paleozoic-triassic chilean magmatism: isotopic approach. Gondwana Res. 37, 172-181.

Delaney, P.T., Pollard, D.D., 1981. Deformation of host rocks and flow of magma during growth of minette dikes and breccia-bearing intrusions near Ship Rock New Mexico. In: U.S. Geological Survey Professional Papers, p. 1202.

Delaney, P.T., Pollard, D.D., Ziony, J.I., McKee, E.H., 1986. Field relations between dikes and joints: emplacement processes and paleostress analysis. J. Geophys. Res.: Solid Earth 91 (B5), 4920-4938.

Domeier, M., Torsvik, T.H., 2014. Plate tectonics in the late Paleozoic. Geoscience Frontiers 5 (3), 303-350.

Eby, G.N., 1987. The monteregian hills and white mountain alkaline igneous provinces, eastern north America. Geol. Soc. Spec. Publ. 30, 433-447.

Einhorn, J.C., Gehrels, G.E., Vernon, A., DeCelles, P.G., 2015. U-Pb zircon geochronology of Neoproterozoic-Paleozoic sandstones and Paleozoic plutonic rocks in the Central Andes (21 $\left.{ }^{\circ} \mathrm{S}-26^{\circ} \mathrm{S}\right)$. Mem. Geol. Soc. Am. 212, 115-124.

Faccenna, C., Rossetti, F., Becker, T.W., Danesi, S., Morelli, A., 2008. Recent extension driven by mantle upwelling beneath the Admiralty Mountains (East Antarctica). Tectonics 27. https://doi.org/10.1029/2007TC002197. TC4015. 
Fernández-Seveso, F., Tankard, A., 1995. Tectonics and stratigraphy of the late paleozoic Paganzo basin of western Argentina and its regional implications. In: Tankard, A.J., Suarez, S., Welsink, H.J. (Eds.), Petroleum Basins of South America, vol. 62. American Association of Petroleum Geologists Memoir, pp. 285-301.

Glazner, A.F., Bartley, J.M., Carl, B.S., 1999. Oblique opening and noncoaxial emplacement of the Jurassic Independence dike swarm, California. J. Struct. Geol. 21 (10), 1275-1283.

Grosse, P., Sollner, F., Baez, M., Toselli, A., Rossi, J., de la Rosa, J., 2009. Lower Carboniferous post-orogenic granites in central-eastern Sierra de Velasco, Sierras Pampeanas, Argentina: U-Pb monazite geochronology, geochemistry and Sr-Nd isotopes. Int. J. Earth Sci. 98 (5), 1001-1025.

Gulbranson, E.L., Montañez, I.P., Schmitz, M.D., Limarino, C.O., Isbell, J.L., Marenssi, S.A., Crowley, J.L., 2010. High-precision U-Pb calibration of Carboniferous glaciation and climate history, Paganzo Group, NW Argentina. Geol. Soc. Am. Bull. 122 (9-10), 1480-1498.

Höckenreiner, M., Söllner, F., Miller, H., 2003. Dating the TIPA shear zone: an Early Devonian terrane boundary between the Famatinian and Pampean systems (NW Argentina). J. S. Am. Earth Sci. 16, 45-66.

Hou, G., 2012. Mechanism for three types of mafic dyke swarms. Geoscience Frontiers 3 (2), 217-223.

Hyppolito, T., García-Casco, A., Juliani, C., Meira, V.T., Hall, C., 2014. Late Paleozoic onset of subduction and exhumation at the western margin of Gondwana (Chilenia Terrane): counterclockwise P-T paths and timing of metamorphism of deep-seated garnet-mica schist and amphibolite of Punta Sirena, Coasta Accretionary Complex, central Chile (34 S). Lithos 206-207, 409-434.

Isbell, J.L., Henry, L.C., Gulbranson, E.L., Limarino, C.O., Fraiser, M.L., Koch, Z.J., Ciccioli, P.L., Dineen, A.A., 2012. Glacial paradoxes during the late Paleozoic ice age: evaluating the equilibrium line altitude as a control on glaciation. Gondwana Res. 22 (1), 1-19.

Jordan, T.E., Allmendinger, R.W., 1986. The Sierras Pampeanas of Argentina: modern analogue of Rocky Mountain foreland deformation. Am. J. Sci. 286 (10) 737-764.

Jordan, T.E., Isacks, B.L., Allmendinger, R.W., Brewer, J.A., Ramos, V.A., Ando, C.J. 1983. Andean tectonics related to geometry of subducted Nazca plate. Geol. Soc. Am. Bull. 94 (3), 341-361.

Jordan, T.E., Zeitler, P., Ramos, V., Gleadow, A.J.W., 1989. Thermochronometric data on the development of the basement peneplain in the Sierras Pampeanas, Argentina. J. S. Am. Earth Sci. 2 (3), 207-222.

Kay, S.M., Mpodozis, C., 2002. Magmatism as a probe to the Neogene shallowing of the Nazca plate beneath the modern Chilean flat-slabs. J. S. Am. Earth Sci. 15 (1), 39-57.

Koppers, A.A.P., 2002. ArArCALC - software for 40Ar/39Ar age calculations. Comput. Geosci. 28 (5), 605-619.

Koukharsky, M., Kleiman, L., Etcheverría, M., Quenardelle, S., Bercowski, F., 2009. Upper Carboniferous retroarc volcanism with submarine and subaerial facies at the western Gondwana margin of Argentina. J. S. Am. Earth Sci. 27 (4) 299-308.

Limarino, C.O., Césari, S.N., Net, L.I., Marenssi, S.A., Gutierrez, R.P., Tripaldi, A., 2002 The Upper Carboniferous postglacial transgression in the Paganzo and Río Blanco basins (northwestern Argentina): facies and stratigraphic significance. J. S. Am. Earth Sci. 15 (4), 445-460.

López, J.P., 2005. Evidencias de dos eventos deformacionales en el flanco noroeste de la Sierra de Velasco. In: Dahlquist, J.A., Baldo, E.G., Alasino, P.H. (Eds.), Geología de la provincia de La Rioja. Precámbrico - Paleozoico Inferior, vol. 8. Asociación Geológica Argentina, Serie D, Special Publication, pp. 149-154.

Maksaev, V., Arancibia, J., Munizaga, F., Tassinari, C., 2015. Detrital-zircon U-Pb geochronology of the Quebrada del Carrizo Metamorphic Complex and El Jardín Schists and spatially-related granitoids of the Sierra Castillo Batholith. Andean Geol. 42 (3), 285-312.

Mannheim, R., 1993. Génesis de las volcanitas eopaleozoicas del Sistema de Famatina, noroeste de Argentina. XII Congreso Geológico Argentino and II Congreso de Exploración de Hidrocarburos. Acta 4, 147-155.

Martina, F., Astini, R.A., 2009. Geología de la región del río Bonete en el antepaís andino (27 $\left.-30^{\prime} \mathrm{LS}\right)$ : extremo norte del terreno de Precordillera. Rev. Asoc. Geol. Argent. 64 (2), 312-328.

Martina, F., Viramonte, J.M., Astini, R.A., Pimentel, M.M., Dantas, E., 2011. Mississippian volcanism in the south-central Andes: new U-Pb SHRIMP zircon geochronology and whole-rock geochemistry. Gondwana Res. 19 (2), 524-534.

Martinez-Poza, A.I., Druguet, E., Castaño, L.M., Carreras, J., 2014. Dyke intrusion into a pre-existing joint network: the Aiguablava lamprophyre dyke swarm (Catalan Coastal Ranges). Tectonophysics 630, 75-90.

Meira, V.T., Campos Neto, M.D.C., González, P.D., Stipp Basei, M.A., Varela, R., 2012 Ordovician klippen structures of the Sierra de Umango: new insights on Tectonic evolution of the Western Sierras Pampeanas, Argentina. J. S. Am. Earth Sci. 37, 154-174.

Min, K., Mundil, R., Renne, P.R., Ludwig, K.R., 2000. A test for systematic errors in $40 \mathrm{Ar} / 39 \mathrm{Ar}$ geochronology through comparison with $\mathrm{U} / \mathrm{Pb}$ analysis of a 1.1-Ga rhyolite. Geochimica and Cosmochima Acta 64, 73-98.

Phillips, D., Matchan, E.L., 2013. Ultra-high precision 40Ar/39Ar ages for Fish Canyon Tuff and Alder Creek Rhyolite sanidine: new dating standards required? Geochemica and Cosmochemica Acta 121, 229-239.

Pinotti, L.P., Coniglio, J.E., Esparza, A.M., D'Eramo, F.J., Llambías, E.J., 2002. Nearly circular plutons emplaced by stoping at shallow crustal levels, Cerro Áspero batholith, Sierras Pampeanas de Córdoba, Argentina. J. S. Am. Earth Sci. 152, $251-265$.

Pinotti, L., Coniglio, J., DEramo, F., Demartis, M., Otamendi, J., Fagiano, M., Zambroni, N., 2014. El Magmatismo Devónico: geología del Batolito Cerro Áspero. In: Martino, R.D., Guereschi, A.B. (Eds.), Relatorio del XIX Congreso Geológico Argentino. Geología y Recursos Naturales de la provincia de Córdoba. Parte I: Geología - A: Geología de Superficie. Asociación Geológica Argentina, pp. 255-276 (Córdoba).

Polanski, J., 1970. Carbónico y Pérmico de la Argentina. EUDEBA, Buenos Aires.

Ramos, V.A., 1988. The tectonics of the Central Andes; $30^{\circ}$ to $33^{\circ} \mathrm{S}$ latitude. Spec. Pap. Geol. Soc. Am. 31-54.

Ramos, V.A., Dallmeyer, R.D., Vujovich, G., 1998. Time constraints on the early palaeozoic docking of the Precordillera, central Argentina. Geol. Soc. Spec. Publ. $142,143-158$.

Rocchi, S., Storti, F., Di Vincenzo, G., Rossetti, F., 2003. Intraplate strike-slip tectonics as an alternative to mantle plume activity for the Cenozoic rift magmatism in the Ross Sea region, Antarctica. In: Storti, F., Holdsworth, R.E., Salvini, F. (Eds.), Intraplate Strike-slip Deformation Belts, vol. 210. Geol. Soc. Spec. Publ., pp. $145-158$

Rothery, E., 1988. En échelon vein array development in extension and shear. J. Struct. Geol. 10 (1), 63-71.

Scarrow, J.H., Molina, J.F., Bea, F., Montero, P., Vaughan, A.P.M., 2011. Lamprophyre dikes as tectonic markers of late orogenic transtension timing and kinematics: a case study from the Central Iberian Zone. Tectonics 30 (4). https://doi.org/ 10.1029/2010TC002755. TC4007.

Siegesmund, S., Steenken, A., López de Luchi, M.G., Wemmer, K., Hoffmann, A., Mosch, S., 2004. The Las Chacras-Potrerillos batholith (Pampean Ranges, Argentina): structural evidences, emplacement and timing of the intrusion. Int. J. Earth Sci. 93 (1), 23-43.

Sims, J.P., Ireland, T.R., Camacho, A., Lyons, P., Pieters, P.E., Skirrow, R.G., StuartSmith, P.G., Miró, R., 1998. U-Pb, Th-Pb and Ar-Ar Geochronology from the Southern Sierras Pampeanas, Argentina: Implications for the Palaeozoic Tectonic Evolution of the Western Gondwana Margin, vol. 142. Geological Society Special Publication, pp. 259-281.

Spagnuolo, C., Rapalini, A., Leal, P., Astini, R., 2008. Emplazamiento de los lamprófiros prepérmicos de la cuesta de miranda (prov. de La Rioja) en base a estudios de fábrica magnética. Acta 17, 49-50. Congreso Geológico Argentino.

Steenken, A., Siegesmund, S., Wemmer, K., López de Luchi, M.G., 2008. Time constraints on the Famatinian and Achalian structural evolution of the basement of the Sierra de San Luis (Eastern Sierras Pampeanas, Argentina). J. S. Am. Earth Sci. 25 (3), 336-358.

Swanson, M.T., 1992. Structural sequence and tectonic significance of Mesozoic dikes in southern coastal Maine. Spec. Pap. Geol. Soc. Am. 37-62.

Sylvester, A.G., 1988. Strike-slip faults. Geol. Soc. Am. Bull. 100 (11), 1666-1703.

Tappe, S., Foley, S.F., Jenner, G.A., Heaman, L.M., Kjarsgaard, B.A., Romer, R.L. Stracke, A., Joyce, N., Hoefs, J., 2006. Genesis of ultramafic lamprophyres and carbonatites at Aillik Bay, Labrador: a consequence of incipient lithospheric thinning beneath the North Atlantic Craton. J. Petrol. 47 (7), 1261-1315.

Tchalenko, J.S., 1970. Similarities between shear zones of different magnitudes. Geol. Soc. Am. Bull. 81 (6), 1625-1640.

Tikoff, B., Teyssier, C., 1992. Crustal-scale, en echelon "P-shear" tensional bridges: a possible solution to the batholithic room problem. Geology 20 (10), 927-930.

Torsvik, T.H., Cocks, L.R.M., 2013. Gondwana from top to base in space and time. Gondwana Res. 24 (3-4), 999-1030.

Toselli, A.J., Saavedra, J., Durand, F.R., Rossi de Toselli, J., Pellitrero, E., 1996. Lamprófiros del Sistema de Famatina. In: Aceñolaza, F., Miller, H., Toselli, A. (Eds.), Geología del Sistema de Famatina. Munchener Geologische Hefte, 19 (Reihe A): 275-281, Munchen.

Toselli, A.J., 1978. Edad de la Formación Negro Peinado, Sierra de Famatina, La Rioja. Rev. Asociación Geológica Argentina 33, 86-89.

Trauth, M.H., Gebbers, R., Marwan, N., Sillmann, E., 2007. MATLAB Recipes for Earth Sciences, vol, 34 Springer, Berlin.

Turner, J.C.M., 1971. Hoja geológica 15d, Famatina, Provincia de La Rioja. República Argentina, Ministerio de Industria y Minería, Subsecretaría de Minería, Dirección Nacional de Geología y Minería.

Van der Meer, Q.H.A., Storey, M., Scott, J.M., Waight, T.E., 2016. Abrupt spatial and geochemical changes in lamprophyre magmatism related to Gondwana fragmentation prior, during and after opening of the Tasman Sea. Gondwana Res. 36, 142-156.

Vaughan, A.P.M., 1996. A tectonomagmatic model for the genesis and emplacement of Caledonian calc-alkaline lamprophyres. J. Geol. Soc. 153 (4), 613-623.

Vaughan, A.P.M., Scarrow, J.H., 2003. K-rich mantle metasomatism control of localization and initiation of lithospheric strike-slip faulting. Terra. Nova 15 (3), 163-169.

Villar Fabre, J.F., Gonzalez, R., Toselli, A.J., 1973. Los lamprófiros intrusivos del granito de la Cuesta de Miranda. Acta Geol. Lilloana 12, 23-60.

Whitmeyer, S.J., 2008. Dating Fault Fabrics Using Modern Techniques of 40Ar/39Ar Thermochronology: Evidence for Paleozoic Deformation in the Eastern Sierras Pampeanas. Journal of the Virtual Explorer, 30, Argentina. https://doi.org/ 10.3809/jvirtex.2008.00207.

Whitmeyer, S.J., Simpson, C., 2004. Regional deformation of the Sierra de San Luis, Argentina: implications for the Paleozoic development of western Gondwana. Tectonics 23 (1). https://doi.org/10.1029/2003TC001542. TC1005. 
Willner, A.P., Gerdes, A., Massonne, H.J., 2008. History of crustal growth and recycling at the Pacific convergent margin of South America at latitudes $29^{\circ}-36^{\circ} \mathrm{S}$ revealed by a U-Pb and Lu-Hf isotope study of detrital zircon from late Paleozoic accretionary systems. Chem. Geol. 253 (3-4), 114-129.

Willner, A.P., Gerdes, A., Massonne, H.J., Schmidt, A., Sudo, M., Thomson, S.N. Vujovich, G., 2011. The geodynamics of collision of a microplate (Chilenia) in Devonian times deduced by the pressure-temperature-time evolution within part of a collisional belt (Guarguaraz Complex, W-Argentina). Contrib. Mineral. Petrol. 162 (2), 303-327.

Wolf, M.B., Saleeby, J.B., 1995. Late jurassic dike swarms in the southwestern sierra Nevada foothills terrane, California: implications for the nevadan orogeny and north american plate motion. Geol. Soc. Am. Spec. Pap. 299, 203-228.

Ziv, A., Rubin, A.M., Agnon, A., 2000. Stability of dike intrusion along preexisting fractures. J. Geophys. Res.: Solid Earth 105 (B3), 5947-5961. 